\title{
Establishing Enzyme Inhibition and membrane stability studies in methanolic extracts of Evolvulus alsinoides
}

\author{
Raja Rao', S. Muralidhar, Talkad ${ }^{2 *}$, H.V. Anil Kumar ${ }^{3}$ and H.R. Umesh ${ }^{4}$ \\ ${ }^{1}$ Research Scholar, Kalinga University, Campus: Village - Kotni, Near Mantralay, \\ Naya Raipur, Pin - 492101, India \\ ${ }^{2}$ P.G. Department of Biotechnology, R\&D Centre, Dayananda Sagar University, Kumaraswamy \\ Layout, Bangalore-560078, India \\ ${ }^{3}$ Department of Environmental Science \& Laboratory for Applied biological Sciences, DVS \\ College of Arts and Science, Shimoga, Karnataka, India \\ ${ }^{4}$ P.G. Department of Biochemistry, R\&D Centre, Dayananda Sagar Institutions, \\ Kumaraswamy Layout, Bangalore-560078, India \\ *Corresponding author
}

A B S T R A C T

\section{Keywords}

Evolvulus alsinoides methanolic extract, flavonoids, polyphenolic compounds, proteinase, lipoxygenase and xanthine oxidase inhibitions.

\section{Article Info \\ Accepted: \\ 20 May 2016 \\ Available Online: \\ 10 June 2016}

Shankhpushpi is botanically termed as Evolvulus alsinoides; the extracts have exhibited antioxidant, anti-ulcer, and immunomodulatory activities. In addition, recently scientific research has disclosed adaptogenic and anti-amnesic properties. The main objective of the present work is to investigate the invitro therapeutic potential activities of methanolic extract of whole plant of Evolvulus alsinoides on albumin denaturation, membrane stabilization test and Proteinase, xanthine oxidase, lipoxygenase inhibitory activities Establishing Anti inflammatory properties, Inhibition of albumin denaturation showed Albumin denaturation in methanolic plant extract $(500 \mu \mathrm{g} / \mathrm{ml}) 82.32 \pm 0.50$ against standard Aspirin $(100 \mu \mathrm{g} / \mathrm{ml}) 68.40 \pm$ 0.40. Membrane stabilization plant extracts: $65.70 \pm 0.60$ against standard Aspirin: 84.20 \pm 0.40 . Xanthine oxidase $\mathrm{IC}_{50}(\mu \mathrm{M}) \pm$ SEM, methanolic extract: $0.42 \pm 1.40$ against standard Allopurinol: $0.20 \pm 0.40$. $\mathrm{IC}_{50}$ of Anti-lipoxygenase Activity $(500 \mu \mathrm{g} / \mathrm{ml}): 52.60$ against standard Indomethacin $(50 \mu \mathrm{g} / \mathrm{ml}): 46.50 \%$. The extract fractions serve as free radical inhibitors or scavenger or acting possibly as primary oxidants and inhibited the heat induced albumin denaturation, proteinase, lipoxygenase and xanthine oxidase (XO), which are agents that directly inhibit the synthesis of uric acid in vivo. Certain active constituents present in Evolvulus alsinoides plant extracts like flavonoids and polyphenolic compounds possess potent Anti inflammatory therapeutic responses.

\section{Introduction}

Extensive research within last three decades has confirmed the molecular basis for most chronic diseases and for the associated inflammation.
The transcription factor, Nuclear FactorkappaB $(\mathrm{NF}-\kappa \mathrm{B})$ that controls over 500 different gene products, has emerged as major mediator of inflammation. Thus 
agents that can inhibit $\mathrm{NF}-\kappa \mathrm{B}$ and diminish chronic inflammation have potential to prevent or delay the onset of the chronic diseases and further even treat them. In an attempt to identify novel anti-inflammatory agents which are safe and effective (Bharat B. Aggarwal, et al 2011),

Evolvulus alsinoides (shankhpushpi which is considered as Medhya Rasayana) is an Ayurvedic drug used for its action on the central nervous system, especially for boosting memory and improving intellect. In the Ayurvedic system of medicine, the whole herb of 'Shankhpushpi' has been employed clinically for centuries for its memory potentiating, anxiolytic and tranquilizing properties. The crude extracts of $E$. alsinoides showed a marked reduction in inflammation and edema in adjuvant induced arthritic rat model (Ganju L, et al., 2003).

Evolvulus alsinoides (L) is a perennial herb belonging to the family Convolvulaceae with a small woody and branched root stock (Austin, 2008). This plant is used in traditional medicine in East Asia, India, Africa and Philippines to cure fever, cough, cold, venereal diseases, azoospermia, adenitis and dementia. It has a known nootropic and anti-inflammatory activity (Singh, 2008). Its use in the treatment of neurodegenerative diseases, asthma and amnesia (Goyal \& Singh, 2005). Pre-clinical research has justified its ancient claim as brain tonic (Singh, 2008). Several other uses reported for this plant include its ability to boost memory and improve intellect (Sethiya et al., 2009), immunomodulatory, adaptogenic as well as anti-oxidant properties (Siripurapu et al., 2005). Singh (2008) reported that Evolvulus alsinoides is used in the Philippines to cure certain bowel irregularities and as a vermifuge and febrifuge. Infusion of roots, stalks and leaves are all used in Nigeria as a stomaachic.

The preliminary phytochemical screening showed that E. alsinoides contains some secondary metabolites such as glycosides, alkaloids, poly phenols, carbohydrates, amino acids and proteins, saponins, volatile oil, flavonoids and tannins (Omogbai BA, et al 2011). The plant contains alkaloids such as betaine, shankhapushpine, B-sitosterol and evolvine. Fresh plant contains volatile oil. These compounds help brain stimulation and increase the ability to concentrate. Early phytochemical studies of this species resulted in the isolation and identification of chemical constituents such as triacontane, pentatriacontane. Four unidentified alkaloids $\mathrm{A}, \mathrm{B}, \mathrm{C}$ and evolvine have also been described.

In many inflammatory disorders there is excessive activation of phagocytes, production of $\mathrm{O}_{2^{-}}, \mathrm{OH}$ radicals as well as non free radicals species $\left(\mathrm{H}_{2} \mathrm{O}_{2}\right)$ (Gilham et $a l ., 1997)$, which can harm severely tissues either by powerful direct oxidizing action or indirect with hydrogen peroxide and $-\mathrm{OH}$ radical formed from $\mathrm{O} 2-$ which initiates lipid peroxidation resulting in membrane destruction. Tissue damage then provokes inflammatory response by production of mediators and chemotactic factors (Lewis, 1989).

The reactive oxygen species are also known to activate matrix metello proteinase damage seen in various arthritic tissues (Cotran et al., 1994).

Free radicals which have one or more unpaired electrons (superoxide, hydroxyl, peroxyl) are produced in normal or pathological cell metabolism and the compounds that can scavenge free radicals have great potential in ameliorating the 
diseases and pathological cells (Halliwell, 1995; Squadriato and Peyor, 1998; Gulcin et al., 2004).

The increase in prevalence of multiple drug resistance has showed down the development of new synthetic antiinflammatory drugs and the new drug is necessary to search for new antiinflammatory from alternative sources. Phytochemicals from medicinal plants showing anti-inflammatory activities have the potential of filling this need because of structures are different from those of the more studied and their those of the more action may too very likely differ (Fabricant and Fanworth, 2001). Phytochemical analysis of methanolic extract of Evolvulus alsinoides proved in total Phenolic content and total Flavonoid and Anti oxidant assay (Zuhaib Zafar, Muralidhar. S. Talkad, et al., 2011).

The present study planned on Methanolic extract of whole plant of Evolvulus alsinoides for albumin denaturation, membrane stabilization test and Proteinase, xanthine oxidase, lipoxygenase inhibitory activities invitro to establish potential therapeutic response of the plant.

\section{Materials and Methods}

\section{Plant Materials and Extraction}

The plant material was collected from the local rural area of Tumkur district in Karnataka state, India. The plant materials were identified and authenticated. The Plant material were air-dried and pulverized in course powder and was loaded in the Soxhlet apparatus for defating with petroleum ether and followed by extraction with methanol. The methanolic extract of Evolvulus alsinoides was subjected to fractionation and dry concentrated extract were used for the study.

\section{Phytochemical Analysis}

Phytochemical analysis was carried out for saponins, flavonoids, steroids, phenol, anthroquinone, alkaloids (Obdoni and Ochuko, 2001) and tannins (Kaur and Arora, 2009) were performed.

\section{In Vitro Anti-inflammatory Activity}

\section{Inhibition of Albumin Denaturation}

Methods of Mizushima and Kobayashi (1968) and Sakat et al. (2010) followed with minor

modifications. The reaction mixture was consisting of test extracts and $1 \%$ aqueous solution of bovine albumin fraction, $\mathrm{pH}$ of the reaction mixture was adjusted using $\mathrm{HCl}$, and incubated at $37^{\circ} \mathrm{C}$ for $20 \mathrm{~min}$, then heated to $51{ }^{\circ} \mathrm{C}$ for $20 \mathrm{~min}$, measured turbidity after cooling spectrophotometrically at $660 \mathrm{~nm}$. The experiment was performed in triplicate. Percent inhibition of protein denaturation was calculated as follows:

$\% \quad$ inhibition $=[\{\mathrm{Abs}$ control- $\mathrm{Abs}$ sample \}/Abs control] x 100,

Where Abs control is the absorbance without sample, Abs sample is the absorbance of sample

Extract/standard

\section{Membrane Stabilization Test}

\section{Preparation of Red Blood Cells (RBCs) Suspension}

Fresh whole human blood $(10 \mathrm{ml})$ was collected and centrifuged at $3000 \mathrm{rpm}$ for $10 \mathrm{~min}$ and were washed three times with equal volume of normal saline. The volume of blood was measured and re constituted as $10 \%$ v/v suspension with normal saline (Sadique et al., 1989; Saket et al., 2010) 


\section{Heat Induced Hemolytic Assay}

The reaction mixture $(2 \mathrm{ml})$ consisted of $1 \mathrm{ml}$ of test sample solution and $1 \mathrm{ml}$ of $10 \%$ RBCs suspension, control sample consists only saline. Aspirin was used as a standard drug. All the centrifuge tubes with reaction mixture were incubated in water bath at $56^{\circ} \mathrm{C}$ for $30 \mathrm{~min}$, cooled and centrifuged at $2500 \mathrm{rpm}$ for $5 \mathrm{~min}$; the absorbance of the supernatants was measured at $560 \mathrm{~nm}$. The experiment was performed in triplicates for all the test samples. Percent membrane stabilization activity was calculated by the formula mentioned above (Shinde et al., 1999; Saket et al., 2010)

\section{Proteinase Inhibitory Action}

The test was performed according to the modified method of (Oyedepo et al, 1995 and Sakat et al, 2010). The reaction mixture (2ml) was containing $0.06 \mathrm{mg}$ trypsin, $1 \mathrm{ml}$ of $20 \mathrm{mM}$ Tris $\mathrm{HCl}$ buffer (pH: 7.4) and $1 \mathrm{ml}$ test sample of different concentrations of methanolic extracts. The reaction mixture was incubated at $37^{\circ} \mathrm{C}$ for $5 \mathrm{~min}$ and then $1 \mathrm{ml}$ of $0.8 \%(\mathrm{~W} / \mathrm{V})$ casein was added. The mixture was inhibited for $20 \mathrm{~min}$ with $2 \mathrm{ml}$ of $70 \%$ perchloric acid, was added to terminate the reaction. Cloudy suspension was centrifuged and the absorbance of the supernatant was measured at $210 \mathrm{~nm}$ against buffer as blank. The experiment was performed in triplicate. The percentage of inhibition of proteinase inhibitory activity was calculated.

\section{Anti-Lipoxygenase Activity}

Anti-Lipoxygenase activity was carried out using linoleic acid as substrate and lipoxidase as enzyme (Shinde et al., 1999). Test samples were dissolved in $0.25 \mathrm{ml}$ of $2 \mathrm{M}$ borate buffer with $\mathrm{pH} 9.0$ and added $0.25 \mathrm{ml}$ of lipoxidase enzyme solution $(20,000 \mathrm{U} / \mathrm{ml})$ and incubated for $5 \mathrm{~min}$ at $25^{\circ} \mathrm{C}$ followed by, $1.0 \mathrm{ml}$ of lenoleic acid solution $(0.6 \mathrm{mM})$ was added, mixed well and absorbance was measured at $234 \mathrm{~nm}$. Indomethcin was used as reference standard; all tests were carried out in triplicate. A dose response curve was plotted to determine the $\mathrm{IC}_{50}$ values. The percent inhibition was calculated from the following equation,

$\%$ inhibition $=[\{$ Abs control- Abs sample\}/Abs control] x 100

\section{Xanthine Oxidase Assay}

Xanthine oxidase activity was assayed (Yamamoto et al, 1993). Briefly, the reaction mixture consisting of $500 \mu \mathrm{l}$ of solution A $(0.1 \mathrm{M}$ phosphate buffer containing $0.4 \mathrm{mM}$ xanthine and $0.24 \mathrm{mM}$ NBT), $500 \mu \mathrm{l}$ of solution B $(0.1 \quad \mathrm{M}$ phosphate buffer containing 0.0449 units $/ \mathrm{ml}$ xanthine oxidase) and $50 \mu \mathrm{l}$ of a $10 \%$ of methanolic plant extracts were incubated in a cuvette at $37^{\circ} \mathrm{C}$ for $20 \mathrm{~min}$. Allopurinol were used as a Standard, the enzyme activity was expressed as the increment in absorption at $300 \mathrm{~nm}$ spectrophotometrically per unit time.

\section{Statistical Analysis}

Analysis of variance (ANOVA) was used to determine the significance of difference between treatment groups $(\mathrm{p}<0.05)$. Means between treatment groups were compared for significance using Duncan's new Multiple Range post test.

\section{Results and Discussion}

\section{Phytochemical Analysis}

The phytochemical screening showed that the methanolic extracts of Evolvulus alsinoides, the tannin, flavonoids, phenol, alkaloids, steroids, anthraquinones and saponins were present. 


\section{Anti Inflammatory Properties}

\section{Inhibition of Albumin Denaturation}

Protein denaturation is a well documented cause in the mechanism of the anti inflammation activity, ability of different concentration of methanolic extracts of plant on protein denaturation was studied. It was effective in inhibiting heat induced albumin denaturation at $500 \mu \mathrm{g} / \mathrm{ml}$ (Table 1). Maximum inhibition 86.32 was observed from plant methanolic extract 82.32, against std, Aspirin: a standard anti-inflammation drug showed the maximum inhibition 68.40 $\%$ at the concentration of $100 \mu \mathrm{g} / \mathrm{ml}$

The experiments carried out in triplicates, According to Duncan's Multiple Range Test (DMRT), values followed by different subscripts are significantly different at $\mathrm{P}<0.05$, mean \pm SEM

\section{Membrane Stabilization Test}

Stabilization of RBCs membrane was establishes the mechanism of antiinflammatory action of different concentrations of methanolic extracts of Evolvulus alsinoides, the extract were effectively inhibiting the heat induced hemolysis, these results provide evidence for membrane stabilization and their antiinflammatory mechanism. This effect may possibly inhibit the release of lysosomal content of neutrophils at the site of inflammation. The extracts inhibited the heat induced hemolysis of RBCs to varying degree (Table 1). The maximum inhibition was recorded $65.70 \pm 0.60$ at $500 \mu \mathrm{g} / \mathrm{ml}$ in methanolic extract of plant, the aspirin as a standard drug showed the maximum inhibition $84.20 \%$.

\section{Proteinase Inhibitory Activity}

The methanolic extracts of Evolvulus alsinoides at different concentration exhibited significant antiproteinase activity. The maximum inhibition was observed from methanol extract (74.80) at $500 \mu \mathrm{g} / \mathrm{ml}$, when compared to the standard drug aspirin the maximum proteinase inhibitor activity is 86.70 (Table 1).

\section{Xanthine Oxidase Assay}

The maximum inhibition of xanthine oxidase was observed from methanolic plant extract $\quad \mathrm{IC}_{50} \quad \mu \mathrm{M} \quad$ (42.00). Maximum inhibition was noticed when compared to the Standard: Allopurinol was 0.20 and Flavonoids: Luteolin + epigallocatechin (1: 1) were 0.62 . (Table: 2 )

\section{Effect of Different Solvent Extracts on Anti-lipoxygenase Activity}

All the extracts significantly inhibited the lipoxygenase activity; it is ranged from 42.50 to 52.60 . The methanolic extracts has showed highest anti-lipoxygenase activity at $500 \mu \mathrm{g} / \mathrm{ml}$ is 52.60 (Table: 2), the standard indomethacin showed a $46.50 \%$ inhibition at a concentration of $50 \mu \mathrm{g} / \mathrm{ml}$.

The ethanol extract of Evolvulus alsinoides had in vitro broad spectrum antimicrobial activity. Thus extracts from the plant can be used to control infections caused by Salmonella typhi, Escherichia coli, Klebsiella pneumoniae and Staphylococcus aureus (Omogbai, BA. and Eze, FA, 2011).

Results of our findings confirmed the use of Evolvulus alsinoides as a traditional medicine. We found strong anti inflammatory activities specifically in the Methanolic extracts of Evolvulus alsinoides. High TPC values found in methanol extract imply the role of phenolic compounds in contributing these activities. Plant phenolic compounds have been found to possess potent anti-inflammatory activity (Sakat $e t$ 
al., 2010; Roy et al., 2010; Garg et al., 2010). These flavonoids have been found to possess anti-inflammatory properties in various studies (Lin et al., 2008; LopezLazaro, 2009; Yoshida et al., 2009; Amarlal et al., 2009).

Strong presence of tannins in all the solvent extracts may explain its potent bioactivities are known to possess potent a antiinflammatory properties (Souza et al., 2007; Fawole et al., 2010). The Saponins have already shown as anti-inflammatory activity (Gepdireman et al., 2005), the presence of terpenoids has shown anti-inflammatory properties (Neichi et al., 1983).

Denaturation of proteins is a well documented causative factor for inflammation. The inflammatory drugs (salicylic acid, phenyl butazone etc) have shown dose dependent ability to thermally induced protein denaturation (Mizushima and Kobayashi, 1968).

Similar results were observed from many reports from plant extract (Sakat et al., 2010). The extracts may possibly inhibit the release of lysosomal content of neutrophils at the site of inflammation. These neutraphils lysosomal constituents include bactericidal enzymes and proteinases, which upon extracellular release cause further tissue inflammation and damage (Chou, 1997). The precise mechanism of this membrane stabilization is yet to be elucidated; it is possible that the methanolic extract of Evolvulus alsinoides produced this effect surface area/volume ratio of the cells, which could be brought about by an expansion of membrane or the shrinkage of cells and an interaction with membrane proteins (Shinde et al., 1999).

Proteinases have been implicated in arthritic reactions. Neutrophils are known to be a source of proteinase which carries in their lysosomal granules many serine proteinases. It was previously reported that leukocytes proteinase play important role in the development of tissue damage during in inflammatory reactions and significant level of protection was provided by proteinase inhibitors (Das and Chatterjee, 1995). Recent studies have shown that many flavonoids and related polyphenols contributed significantly to the antiinflammatory activities of many plants (Luo et al., 2002; Okoli and Akah, 2004).

The mode of action of the extracts and standard anti-inflammatory drugs could be connected with binding to the erythrocyte membranes with subsequent alteration of the surface charges of the cells (Hess SM et al 1972). It has been reported that certain saponins and flavanoid exerted stabilizing effect on lysosomal membrane both invivo and invitro while tannins and saponins possess ability to bind cations, thereby stabilizing erythrocyte membranes and other biological macromolecules (Van-Cangeghen P, 1972).

Hence, the presence of bioactive compounds in the methanol and ethanol extracts of ethanol extract of Evolvulus alsinoides may contribute to its, antimicrobial, antioxidant and anti inflammatory activity. The present investigation has shown that the different solvent extracts of methanolic extract of Evolvulus alsinoides have shown the presence of active phytochemicals which are showed significantly anti-inflammatory properties were confirmed.

These activities may be due to strong occurrence of polyphenolic compounds such as alkaloids, flavonoids, tannins, steroids, terpenoids, phenols and Saponins. The antiinflammatory activity was comparable with standard aspirin. 
This medicinal plant by in vitro results appear to be establishing scientific evidence to support traditional medicinal uses and indicate a promising potential for the development of an anti-inflammatory agent from methanolic extract of Evolvulus alsinoides plant.

LOXs are sensitive to antioxidants and the most of their action may consist in inhibition of lipid hydroperoxide formation due to scavenging of lipidoxy or lipid peroxyradical formed in course of enzyme peroxidation. This can limit the availability of lipid hydroperoxide substrate necessary for the catalytic cycle of LOX. The results obtained from our studies on ethanol extract of Evolvulus alsinoides has shown as potential anti-inflammatory activity.

\section{The ethanol extract of Evolvulus alsinoides inhibited the lipoxygenase enzyme activity.}

This indicates that plant ethanolic extract of Evolvulus alsinoides is more useful in studies of inflammation and in various related physiological studies and diseases such as aging, cancer etc. activity and stabilized the Red Blood Cells membrane. The solvent fractions exhibited a moderate XO inhibitory activity and therefore may due to presence of bioactive constituents and these can useful in the treatment of XO induced diseases.

Many studies have suggested that flavonoids exhibit biological activities, including antiallergenic, antiviral, anti-inflammatory, and vasodilating actions. These pharmacological effects are linked to the antioxidant properties of flavonoids. Protective effects of flavonoids are ascribed to their capacity to suppress ROS formation by inhibiting some enzymes or chelating trace elements involved in free radical production, scavenge radical species and more specially the ROS, and improve regulation antioxidant defense (Ferrali, et al 1997, Elliott, et al 1992, Hirano, R. et al 2001, Cotelle, et al 1996).

Table.1 Effect of methanolic extract of evolvulus alsinoides on albumin denaturation, membrane stabilization and proteinase inhibitory activity percentage inhibition

\begin{tabular}{|l|l|l|l|}
\hline Test sample & $\begin{array}{l}\text { Albumin } \\
\text { denaturation }\end{array}$ & $\begin{array}{l}\text { Membrane } \\
\text { stabilization }\end{array}$ & Proteinase inhibition \\
\hline $\begin{array}{l}\text { Methanolic } \\
\text { extract }(500 \mu \mathrm{g} / \mathrm{ml})\end{array}$ & $82.32 \pm 0.50 \mathrm{a}$ & $65.70 \pm 0.60 \mathrm{~b}$ & $74.80 \pm 0.80 \mathrm{~b}$ \\
\hline Aspirin $(100 \mu \mathrm{g} / \mathrm{ml})$ & $68.40 \pm 0.40 \mathrm{c}$ & $84.20 \pm 0.40 \mathrm{a}$ & $86.70 \pm 0.50 \mathrm{a}$ \\
\hline
\end{tabular}

Table.2 Effect of methanolic extract of Evolvulus alsinoides on Xanthine oxidase, Anti-lipoxygenase inhibitory activity percentage inhibition

\begin{tabular}{|l|l|l|}
\hline Test sample & $\begin{array}{l}\text { Xanthine oxidase } \\
\mathrm{IC}_{50}(\mu \mathrm{M}) \pm \mathrm{SEM}\end{array}$ & $\begin{array}{l}\text { Anti-lipoxygenase } \\
\text { Activity }\left(\mathrm{IC}_{50} \mu \mathrm{g} / \mathrm{ml}\right)\end{array}$ \\
\hline $\begin{array}{l}\text { Methanolic } \\
\text { extract }(500 \mu \mathrm{g} / \mathrm{ml})\end{array}$ & $0.42 \pm 1.40 \mathrm{a}$ & 52.60 \\
\hline Std : Allopurinol & $0.20 \pm 0.40$ & ------- \\
\hline $\begin{array}{l}\text { Luteolin }+ \\
\text { epigallocatechin }(1: 1)\end{array}$ & $0.62 \pm 0.20$ & ----- \\
\hline $\begin{array}{l}\text { Std : Indomethacin } \\
(50 \mu \mathrm{g} / \mathrm{ml}) .\end{array}$ & --------- & $46.50 \%$ \\
\hline
\end{tabular}


Xanthine oxidase inhibitors (XOI) are typically used in the treatment of nephropathy and renal stone diseases linked to hyperuricemia. There has been recent interest in the potential benefit of XOI in the prevention of vascular disease, because of emerging evidence suggesting a role for serum uric acid in the development of cardiovascular disease; the enzyme is an important source of oxidative stress in the vasculature (Higgins, $\mathrm{P}$ et al 2009). XOI are agents that directly inhibit the synthesis of uric acid in vivo. Certain active constituents present in crude plant extracts like flavonoids and polyphenolic compounds have been reported to possess XOI (Chang, W. S. et al 1993, Costantino, L. et al 1992). These findings have opened the possibility of isolation of new natural compounds, which can be possible inhibitors of $\mathrm{XO}$, and led to the growing interest in the investigation of medicinal plants. The activity of flavonoids as inhibitors of xanthine oxidase in vitro has been reported. The absence of a hydroxyl group at C-3 enhances slightly the inhibition effect on XO (Cos P. L, et al 1998, Van Hoorn, D. E. C. et al 2002, Arimboor, R. et al 2011).

These extracts also exhibited antioxidant and anti-inflammatory properties strongly. These extracts reduced the activity of lipoxygenase, xanthine oxidase activities. Purification of each bioactive compound can be needed and purified compound can also increase their activity. This report proposing its potential application as a lead compounds for designing potent anti-inflammatory activity and they can be used for treatment of various diseases (Cancer, neurological disorder, aging and inflammatory).

In conclusion, the present study results indicated that the methanolic extract of Evolvulus alsinoides possess antioxidant and anti-inflammatory properties. The extract fractions serve as free radical inhibitors or scavenger or acting possibly as primary oxidants and inhibited the heat induced albumin denaturation, proteinase, lipoxygenase and xanthine oxidase (XO), which may serve as therapeutic agents for hyperuricemia and/or gout. Xanthine oxidase inhibitors are agents that directly inhibit the synthesis of uric acid in vivo. Certain active constituents present in crude plant extracts like flavonoids and polyphenolic compounds have been reported to possess XOI.

These therapeutic responses were due to the strong occurrence of polyphenolic compounds in Evolvulus alsinoides plant extracts

\section{Acknowledgements}

The authors are extremely grateful to Dr. Premchandra Sagar, Vice Chairman, Dayananda Sagar Institutions and Dr. Sunil More, Dean, Life Sciences, Dayananda Sagar University, Bangalore -560078, INDIA, for their immense guidance and support for this project.

\section{Reference}

Amarlal, S., Mira L., Nogueira J.M., Da Silva A.P., Helena Florencio M. 2009. Plant extracts with antiinflammatory properties-a new approach for characterization of their bioactive compounds and establishment of structure-antioxidant activity relationships. Bioorg Med Chem., 17(5): P.1876-1883.

Arimboor, R., Rangan, M., Aravind, S.G., and Arumughan. $\quad$ C. 2011. Tetrahydroamentoflavone (THA) from Semecarpus anacardium as a potent inhibitor of xanthine oxidase. Journal of Ethnopharmacology., vol. 133(3): 11171120 
Austin, D. F. 2008. Evolvulus alsinoides (Convolvulaceae). An American herb in the old world. Journal of Ethnopharmacology., 117(2): 185-198

Bharat,B,. Aggarwal, Sahdeo Prasad., Simone Reuter., Ramaswamy Kannappan., Vivek R. Yadev., Byoungduck Park., Ji Hye Kim., Subash C. Gupta., Kanokkarn Phromnoi., Chitra Sundaram., Seema Prasad., Madan M, Chaturvedi., and Bokyung Sung. 20110ct1. Identification of Novel Antiinflammatory Agents from Ayurvedic Medicine for Prevention of Chronic Diseases. "Reverse Pharmacology" and "Bedside to Bench" Approach. Curr Drug Targets., 12(11): 1595-1653.

Chang,W.S., Lee, Y.J., Lu, F.J., and Chiang, H.C. 1993. Inhibitory effects of flavonoids on xanthine oxidase. Anticancer Research., vol. 13(6): 2165 2170.

Chou C.T. 1997. The anti-inflammatory effect of Tripterygium wilfordii Hook $\mathrm{F}$ on adjuvant induced paw edema in rats and inflammatory mediator's release. Phytother Res., 11:152- 154.

Costantino, L., Albasini, A., Rastelli, G., and Benvenuti., S. 1992. Activity of polyphenolic crude extracts as scavengers of superoxide radicals and inhibitors of xanthine oxidase. Planta Medica., vol.58 (4): 342-344.

Cos, P.L., Ying, M., Calomme. 1998. Structure-activity relationship and classification of flavonoids as inhibitors of xanthine oxidase and superoxide scavengers. Journal of Natural Products., vol. 61(1): 71-76,

Cotran R.S., Kumar V., Robbins S.L., Schoen F.J .1994. Inflammation and repair: in Robbins Pathologic Basis of Disease. Philadelphia. (Ed.): WB Saunders Company, 51-93.

Cotelle, N., Bernier, J.L., Catteau, J.P., Pommery, J., Wallet, J.C and Gaydou, E.M. 1996. Antioxidant properties of hydroxyflavones. Free Radical Biology and Medicine., vol. 20(1): 35-43.
Das SN., Chatterjee S. 1995. Long term toxicity study of ART-400. Indian Indg Medicine., 16(2):117-123.

Elliott, A. J., Scheiber, S. A., Thomas C., and Pardini, R. S. 1992. Inhibition of glutathione reductase by flavonoids. A structure activity study. Biochemical Pharmacology., vol. 44(8): 1603-1608.

Fabricant D.S., Fansworth N.R. 2001. The value of plants used in traditional medicine for drug discovery. Environment Health Perspective., 109: 69-75.

Fawole O.A., Amoo S.O., Ndhlala A.R., Light M.E., Finnie J.F., Van Staden J. 2010. Anti-inflammatory, anticholinesterase, antioxidant and phytochemical properties of medicinal plants used for pain-related ailments in South Africa. $J$. Ethnopahmacol., 127(2):235- 241.

Ferrali, M., Signorini, C., Caciotti B. 1997. Protection against oxidative damage of erythrocyte membrane by the Flavonoid quercetin and its relation to iron chelating activity. FEBS Letters., 416 (2): 123-129.

Ganju, L., Karan, D., Chanda, S., Srivastava K.K., Sawhney R.C., Selvamurthy, W. 2003 Sep. Immunomodulatory effects of agents of plant origin. Biomed Pharmacother., 57(7): 296-300.

Garg, V.K.R., Jain, M., Sharma, P.K.R., Garg, G. 2010. Anti inflammatory activity of Spinacia oleracea. International Journal of Pharma Professional's Research., 1(1):1-4.

Gepdireman, A., Mshvildadze, V., Suleyman, H., Elias, R. 2005. Acute antiinflammatory activity of four saponins isolated from ivy: alpha-hederin, hederasaponin-C, hedera-colchiside-E and hedera- colchiside $\mathrm{F}$ in carrageenaninduced rat paw edema. Phytomedicine. 12(6-7): 440-444.

Gilham, B., Papachristodoulou, K., Thomas J.H. 1997. Wills Biochemical Basis of medicine. $\quad\left(3^{\text {rd }}\right.$ Edn $)$ Oxford: Butterworth-Heinemenn, 49-82. 
Goyal, P. R. \& Singh, K. P. (2005). Evolvulus alsinoides Linn. A medicinal herb. International Journal of Mendel. 22(3-4): 124-125.

Gulcin, I., Mshvildadze, V., Gepdiremen, A, Elias R. 2004. Antioxidant activity of saponins isolated from ivy: alphahederin, hederasaponin-C, hederacolchiside-E and hederacolchiside-F. Planta Medica., 70(6):561-563.

Halliwell, B. 1995. How to characterize an antioxidant: an update. Biochemical Society Symposia., 61: 85-91.

Hess, S.M., and Milloning, R.C. 1972. In Inflammation, Mechanism and Control, Lepow, L.H and Wards, P.A., Eds, Academic Press, New York : 1-72.

Higgins, P., Dawson, J., and Walters, M. 2009. The potential for xanthine oxidase inhibition in the prevention and treatment of cardiovascular and cerebrovascular disease. Cardiovascular Psychiatry and Neurology., Article ID 282059: 9 pages.

Hirano, R., Sasamoto, W., Matsumoto, A., Itakura, H., Igarashi, O., and Kondo, K. 2001. Antioxidant ability of various flavonoids against DPPH radicals and LDL oxidation. Journal of Nutritional Science and Vitaminology., vol. 47(5): 357-362.

Kaur, G.J, Aroara, D.S. 2009. Antibacterial and Phytochemical screening of Anthum graveolens, Foeniculum vulgare and Trachyspermum ammi. BMC Complement Altern., 9:30.

Lewis, D.A. 1989. Anti-inflammatory drugs from plants and marine sources. Basel: Bikhauser Verlag, pp. 137-164.

Lin, Y., Shi, R., Wang, X., Shen, H.M. 2008. Luteolin, a flavonoid with potential for cancer prevention and therapy. Curr Cancer Drug Targets., 8:634-46.

Lopez-Lazaro, M. 2009. Distribution and biological activities of the flavonoid luteolin. Mini Rev Med Chem., 9:31-59.

Luo, X.D., Basile, M.J, Kennelly, E.J. 2002. Polyphenolic antioxidants from the fruits of Chrysophyllum cainito L. (star apple). Journal of Agriculture and Food Chemistry., 50:1379- 1382.

Mizushima, Y., Kobayashi, M. 1968. Interaction of anti -inflammatory drugs with serum proteins, especially with some biologically active proteins. Journal of Pharma Pharmacology., 20:169-173.

Neichi, T., Koshihara, Y., Murota, S. 1983. Inhibitory effect of esculetin on 5lipoxygenase and leukotriene biosynthesis. Biochim Biophys Acta., 753:130 -132.

Obdoni, B.O., Ochuko, P.O. 2001. Phytochemical studies and comparative efficacy of the crude extract of some homostatic plants in Edo and Delta States of Nigeria. Glob. J. Pure Appl. Sci., 8b:203-208.

Okoli, C.O, Akah, P.A. 2004. Mechanism of the anti-inflammatory activity of the leaf extracts of Culcasia scandens P. beauv (Araceae). Pharmacology, Biochemistry and Behaviour., 79:473-481.

Omogbai, B. A., and Eze, F. A. 2011. Phytochemical Screening and phytochemical Screening and Susceptibility of Bacteria Pathogens to extracts of Evolvulus alsinoides. Science World Journal., 6 (1): p5

Oyedepo, O.O, Femurewa, A.J. 1995. Antiprotease and membrane stabilizing activities of extracts of Fagra zanthoxiloides, Olax subscorpioides and Tetrapleura tetraptera. Int J Pharmacog., 33:65-69.

Roy, S.P, Niranjan, C.M, Jyothi, T.M, Shankrayya, M.M, Vishawanath, K.M, Prabhu, K., Gouda, V.A., Setty, R.S. 2010. Antiulcer and anti-inflammatory activity of aerial parts Enicostemma littorale Blume. Pharmacology., 2(4): 369-373.

Sadique, J., Al-Rqobahs W.A., Bughaith., EI Gindi Ar.1989. The bioactivity of certain medicinal plants on the stabilization of 
RBS membrane system. Fitoterapia., 60:525-532.

Sakat, S., Juvekar, A.R., Gambhire, M.N. 2010. In vitro antioxidant and antiinflammatory activity of methanol extract of Oxalis corniculata Linn. International Journal of Pharma and Pharmacological Sciences., 2(1):146155.

Sethiya, N. K., Nahata, A., Dixit, V. K., Mishra, S. H. 2009. Shankhpushpi: Cognition boosting ayurvedic medicine An update. Journal of Chinese Integration Medicine., 7:1001-22.

Shinde, U.A, Phadke, A.S, Nari, A.M., Mungantiwar, A.A., Dikshit, V.J., Saraf, M.N. 1999. Membrane stabilization activity - a possible mechanism of action for the anti-inflammatory activity of Cedrus deodara wood oil. Fitoterapia., 70:251-257.

Singh, A. (2008). Review of Ethnomedicinal uses and pharmacology of Evolvulus alsinoides Linn. Ethnobotanical leaflets $12: 734-740$

Siripurapu, K. B., Gupta, P., Bhatia, G., Maurya, C., Nath, C., \& Palit, G. 2005. Adaptogenic and anti-amnesic properties of Evolvulus alsinoides in rodents. Pharmacology Biochemistry and Behaviour., 21:424-432.

Souza, S.M., Aquino, L.C., Milach, A.C Jr., Bandeira, M.A., Nobre, M.E., Viana, G.S. 2007. Anti-inflammatory and antiulcer properties of tannins from Myracrodruon urundeuva Allemão
(Anacardiaceae) in rodents. Phytother Res., 21(3):220-225.

Squadriato, G.L, Peyor, W.A. 1998. Oxidative chemistry of nitric oxide: the role of superoxide, peroxynitric and carbon dioxide. Free Radical Biology and Medicine., 25:392- 403.

Van-Cangeghen, P. 1972. Influence of some hydrosoluble substances with Vitamin P activity on the fragility of lysosomes in vitro. Biochem. Toxicol., 11:1543-1548.

Van Hoorn, D. E. C., Nijveldt, R. J., van Leeuwen , P. A. M. 2002. Accurate prediction of xanthine oxidase inhibition based on the structure of flavonoids. European Journal of Pharmacology., 451(2): 111-118.

Yamamoto, Y., Miura, Y., Higuchi, M., Kinoshita, Y., Yoshimura, I. 1993. Using lichen tissue cultures in modern biology. Bryologist. 96(3): 384-393.

Yoshida, T., Konishi, M., Horinaka, M., Yasuda, T., Goda, A.E., Taniguchi, H., Yano, K., Wakada, M., Sakai, T. 2008. Kaempferol sensitizes colon cancer cells to TRAIL induced apoptosis. Biochem and Biophys Res Comm., 375:129-133.

Zuhaib Zafar, Muralidhar.S. Talkad, Chinmay Bandopadhyay, Madhurima Sinha., Jinnia Sarkhel. 2011. Antioxidant Activity of Five Selective Medicinal Plants. African Journal of Scientific Research, Vol. 2: No. 1. 126-147.

\section{How to cite this article:}

Raja Rao, S. Muralidhar, Talkad, H.V. Anil Kumar and Umesh, H.R. 2016. Establishing Enzyme Inhibition and membrane stability studies in methanolic extracts of Evolvulus alsinoides. Int.J.Curr.Microbiol.App.Sci. 5(6): 990-1000.

doi: http://dx.doi.org/10.20546/ijcmas.2016.506.105 